did not add any useful information or change infection control practices compared to symptom-based screening.

To our knowledge, this is the first study to evaluate the benefit of asymptomatic testing for hospitalized patients in a low-prevalence setting. In a New York hospital, universal testing of women admitted for delivery showed $13.5 \%$ asymptomatic positive SARS-CoV-2 results. $^{10}$ In contrast, our study found no asymptomatic positive cases. This finding is likely due to differences in local prevalence.

The strengths of our study include the systematic approach to testing. Also, the inclusion of 4 hospitals makes the results more generalizable. Our study has 2 limitations. First, repeated pointprevalence testing would have yielded more precise results, but this method would not have been feasible given the capacity of our virology laboratory. Second, nasopharyngeal swabbing may produce false-negative results, given its estimated sensitivity between $75 \%$ and $95 \% .{ }^{4}$ Although imperfect, nasopharyngeal swabbing is practical and is currently the recommended test for asymptomatic patients. ${ }^{4}$

In conclusion, our study suggests the minimal utility of asymptomatic testing in hospitalized patients compared to symptom screening and targeted testing in low-prevalence settings, which supports the current IDSA guidelines. ${ }^{4}$

Acknowledgments. None.

Financial support. No financial support was provided relevant to this article.

\section{References}

1. Wang D, Hu B, Hu C, et al. Clinical characteristics of 138 hospitalized patients with 2019 novel coronavirus-infected pneumonia in Wuhan, China. JAMA 2020;323:1061-1069.

2. Kimball A, Hatfield KM, Arons M, et al. Asymptomatic and presymptomatic SARS-CoV-2 infections in residents of a long-term care skilled nursing facility-King County, Washington, March 2020. Morb Mortal Wkly Rept 2020;69:377.

3. Bai Y, Yao L, Wei T, et al. Presumed asymptomatic carrier transmission of COVID-19. JAMA 2020;323:1406-1407.

4. Hanson KE, Caliendo AM, Arias CA, et al. IDSA guidelines on the diagnosis of COVID-19. Infectious Diseases Society of America website. https://www. idsociety.org/practice-guideline/covid-19-guideline-diagnostics/. Published May 6, 2020. Accessed July 20, 2020.

5. Status of cases in Hamilton. City of Hamilton website. https://www. hamilton.ca/coronavirus/status-cases-in-hamilton. Accessed June 3, 2020.

6. COVID-19 provincial testing guidance update, April 8, 2020. Ministry of Health Ontario website. http://www.health.gov.on.ca/en/pro/programs/ publichealth/coronavirus/docs/2019_covid_testing_guidance.pdf. Published April 8, 2020. Accessed April 13, 2020.

7. Guan WJ, Ni ZY, Hu Y, et al. Clinical characteristics of coronavirus disease 2019 in China. N Engl J Med 2020;382:1708-1720.

8. Charlson ME, Pompei P, Ales KL, MacKenzie CR. A new method of classifying prognostic comorbidity in longitudinal studies: development and validation. J Chronic Dis 1987;40:373-383.

9. He $\mathrm{X}$, Lau EH, Wu $\mathrm{P}$, et al. Temporal dynamics in viral shedding and transmissibility of COVID-19. Nat Med 2020;26:672-675.

10. Sutton D, Fuchs K, D'alton M, Goffman D. Universal screening for SARS-CoV-2 in women admitted for delivery. $N$ Engl J Med Published April 13, 2020. Accessed July 20, 2020.

\title{
Prolonged shedding of severe acute respiratory coronavirus virus 2 (SARS-CoV-2) RNA among patients with coronavirus disease 2019 (COVID-19)
}

\author{
Jessica P. Ridgway MD, MS ${ }^{1}$ (1), Nirav S. Shah MD, MPH ${ }^{2}$ and Ari A. Robicsek MD ${ }^{3}$ \\ ${ }^{1}$ Department of Medicine, University of Chicago, Chicago, Illinois, ${ }^{2}$ NorthShore University HealthSystem, Evanston, Ilinois and ${ }^{3}$ Providence St. Joseph Health, \\ Renton, Washington
}

Early reports from China indicate that severe acute respiratory coronavirus virus 2 (SARS-CoV-2) RNA may persist in the respiratory tracts of patients with coronavirus disease 2019 (COVID-19) for several weeks after symptom onset. ${ }^{1-3}$ However, the duration of SARS-CoV-2 RNA shedding has not been systematically studied in a large cohort of patients.

\section{Methods}

To estimate the duration of SARS-CoV-2 RNA shedding, we conducted a multisite study among patients who had nasopharyngeal

\footnotetext{
Author for correspondence: Jessica Ridgway, E-mail: Jessica.ridgway@uchospitals.edu Cite this article: Ridgway JP, Shah NS, and Robicsek AA. (2020). Prolonged shedding of severe acute respiratory coronavirus virus 2 (SARS-CoV-2) RNA among patients with coronavirus disease 2019 (COVID-19). Infection Control \& Hospital Epidemiology, 41: 1235-1236, https://doi.org/10.1017/ice.2020.307
}

specimens tested for SARS-CoV-2 RNA via real-time polymerase chain reaction (PCR) assay at Providence St Joseph Health (a 51-hospital healthcare organization based in Renton, Washington), University of Chicago Medicine in Chicago, Illinois, and NorthShore University HealthSystem (a 5-hospital healthcare system based in Evanston, Illinois). All patients with a positive SARS-CoV-2 PCR test between January 22, 2020, and April 23, 2020 who had at least 1 subsequent SARS-CoV-2 PCR test were included in the study. SARS-CoV-2 PCR tests were ordered at the discretion of medical providers at each institution. We calculated the percentage of patients with a persistent positive SARS-CoV-2 PCR test result up to 25 days after the first positive test. This study was approved by the institutional review board of each institution.

(C) 2020 by The Society for Healthcare Epidemiology of America. All rights reserved. This is an Open Access article, distributed under the terms of the Creative Commons Attribution licence (http://creativecommons.org/licenses/by/4.0/), which permits unrestricted re-use, distribution, and reproduction in any medium, provided the original work is properly cited. 
Table 1. Duration of SARS-CoV-2 RNA Detection

\begin{tabular}{lc}
\hline $\begin{array}{l}\text { No. of Days After } \\
1^{\text {st }} \text { Positive }\end{array}$ & Subsequent \\
SARS-CoV-2 PCR Test & Positive SARS-CoV-2 \\
PCR Tests, \\
No./Total $\%)$
\end{tabular}

Note. PCR, polymerase chain reaction assay.

\section{Results}

During the study period, 76,040 SARS-CoV-2 PCR tests were performed among 70,406 unique patients. The mean age of all patients tested was 48.3 years. Of these patients, 10,584 (15\%) tested positive for SARS-CoV-2. Of these 10,584 patients, 555 (5\%) with an initial positive test for SARS-CoV-2 RNA underwent at least 1 subsequent SARS-CoV-2 PCR test within 25 days of the first test. The mean age of patients who tested positive and had a subsequent test was 61.7 years. Among 156 patients with a subsequent test $1-5$ days after their initial positive test, $138(88 \%)$ continued to have a positive test (Table 1 ). Among 105 patients with a subsequent test 21-25 days after their initial positive test, 59 (56\%) continued to have a positive test.

\section{Discussion}

In this multicenter US study, we found that SARS-CoV-2 RNA shedding persists for $>3$ weeks in most patients with COVID-19. This finding has important implications for infection prevention in both inpatient and outpatient settings. The Centers for Disease Control and Prevention recommends 2 possible strategies for determining when isolation precautions can be discontinued for symptomatic patients with COVID-19: a symptombased strategy and a test-based strategy. ${ }^{4}$ In the symptom-based strategy, isolation precautions can be discontinued 3 days after patient recovery and 10 days after symptom onset, whichever is longer. In the test-based strategy, isolation precautions can be discontinued after improvement in symptoms and at least 2 negative SARS-CoV-2 PCR tests collected at least 24 hours apart. ${ }^{4}$ Our findings that SARS-CoV-2 PCR tests remain positive for $>3$ weeks in most patients suggest that patients following the test-based strategy may remain on precautions for prolonged periods.

Our results are consistent with smaller studies that have also found prolonged duration of SARS-CoV-2 RNA positivity among patients with COVID-19. ${ }^{1,2,5,6} \mathrm{He}^{-} \mathrm{al}^{2}$ examined the dynamics of viral shedding among 94 patients with COVID-19 and found that the SARS-CoV-2 tended to decrease below the detectable limit $\sim 21$ days after symptom onset. Xiao et $\mathrm{al}^{5}$ examined 56 patients with COVID-19 and found a median time from symptom onset to negative PCR test of 24 days. A positive PCR test does not necessarily correlate with viral transmissibility. Indeed, others have found no viable SARS-CoV-2 virus in culture among patients with prolonged SARS-CoV-2 RNA detection. ${ }^{7-9}$
Our study has several limitations. It was a retrospective cohort study among patients with COVID-19 who underwent SARSCoV-2 PCR testing at the discretion of their medical providers. Patients with COVID-19 who are subsequently retested for SARS-CoV-2 are often inpatients being considered for transfer to a nursing home or other long-term care facility. These patients may be older and have more chronic medical conditions than COVID-19 patients in the outpatient setting, so our findings may not be representative of all individuals with COVID-19. We did not collect the clinical characteristics of patients in this analysis. In addition, we were not able to assess SARS-CoV-2 PCR test results in relation to the timing of symptom onset. Patients typically develop symptoms before they undergo their first SARS-CoV-2 PCR test. Therefore, our findings likely underestimate the duration of SARS-CoV-2 RNA shedding.

In conclusion, in a multisite cohort study, we found prolonged duration of SARS-CoV-2 RNA shedding among patients with COVID-19. More research is needed to understand the duration of SARS-CoV-2 transmissibility among patients with COVID-19.

\section{Acknowledgments.}

Financial support. No financial support was provided relevant to this article.

Conflicts of interest. All authors report no conflicts of interest relevant to this article.

\section{References}

1. Zhou F, Yu T, Du R, et al. Clinical course and risk factors for mortality of adult inpatients with COVID-19 in Wuhan, China: a retrospective cohort study. Lancet 2020;395:1054-1062.

2. He X, Lau EHY, Wu P, et al. Temporal dynamics in viral shedding and transmissibility of COVID-19. Nat Med 2020;26:672-675.

3. Xing Y, Mo P, Xiao Y, Zhao O, Zhang Y, Wang F. Post-discharge surveillance and positive virus detection in two medical staff recovered from coronavirus disease 2019 (COVID-19), China, January to February 2020. Euro Surveill 2020;25:2000191.

4. Discontinuation of transmission-based precautions and disposition of patients with COVID-19 in healthcare settings (interim guidance). Centers for Disease Control and Prevention website. https:/www.cdc.gov/coronavirus/2019-ncov/ hcp/disposition-hospitalized-patients.html. Updated May 2, 2020. Accessed May 5, 2020.

5. Xiao AT, Tong YX, Zhang S. Profile of RT-PCR for SARS-CoV-2: a preliminary study from 56 COVID-19 patients. Clin Infect Dis 2020 Apr 19 [Epub ahead of print]. doi: 10.1093/cid/ciaa460.

6. COVID-19 Investigation Team. Clinical and virologic characteristics of the first 12 patients with coronavirus disease 2019 (COVID-19) in the United States. Nat Med 2020;26:861-868.

7. Wolfel R, Corman VM, Guggemos W, et al. Virological assessment of hospitalized patients with COVID-19. Nature 2020;581:465-469.

8. Findings from investigation and analysis of re-positive cases. Korean Centers for Distates Control and Prevention website. https://www.cdc.go.kr/board/ board.es? $\mathrm{mid}=\mathrm{a} 30402000000 \&$ bid $=0030 . \quad$ Published May 19, 2020. Accessed June 8, 2020.

9. Position statement from the National Centre for Infectious Diseases and the Chapter of Infectious Disease Physicians, Academy of Medicine, Singapore23 May 2020. Academy of Medicine Singapore webstie. https://www.ams. edu.sg/view-pdf.aspx?file=media\%5c5556_fi_331.pdf\&ofile=Period + of + Infectivity + Position + Statement $+($ final $)+23-5-20+(\log o s) \cdot$ pdf. Accessed June 8, 2020. 